\title{
Erratum to: Proportion of prokaryotes enumerated as viruses by epifluorescence microscopy
}

\author{
Carlos Mendes • Luísa Santos • Ângela Cunha • \\ Newton C. M. Gomes • Adelaide Almeida
}

Published online: 17 November 2013

(C) Springer-Verlag Berlin Heidelberg and the University of Milan 2013

Erratum to: Ann Microbiol

DOI 10.1007/s13213-013-0713-y

The original version of this article unfortunately contained spelling error. The name of "Newton C. M. Gomes" is now corrected in the author group of this article.

The online version of the original article can be found at doi: http://dx.doi. org/10.1007/s13213-013-0713-y.

C. Mendes $\cdot$ L. Santos · A. Cunha · N. C. M. Gomes ·

A. Almeida $(\square)$

Department of Biology and CESAM, University of Aveiro,

3810-193 Aveiro, Portugal

e-mail: aalmeida@ua.pt 